\title{
The Role of Internal Optical Urethrotomy in the Treatment of Male Urethral Stricture
}

\author{
Alaa Al-Deen Al-Dabbagh, Zaeem Fezea Dahla \\ Department of Surgery, College of Medicine, Al-Mustansiriyah University, Baghdad, Iraq \\ Email: alaaa1962@yahoo.co.uk, dr.zaeemdehla@gmail.com
}

How to cite this paper: Al-Dabbagh, A.A.-D. and Dahla, Z.F. (2018) The Role of Internal Optical Urethrotomy in the Treatment of Male Urethral Stricture. Open Journal of Urology, 8, 327-335. https://doi.org/10.4236/oju.2018.812036

Received: October 29, 2018

Accepted: December 11, 2018

Published: December 14, 2018

Copyright ( $) 2018$ by authors and Scientific Research Publishing Inc. This work is licensed under the Creative Commons Attribution International License (CC BY 4.0).

http://creativecommons.org/licenses/by/4.0/

(c) (i) Open Access

\begin{abstract}
Background: Male urethral stricture is as yet considered one of the very popular and defying dilemmas to the urologist. Treatment modalities include dilation, endoscopic urethrotomy and urethroplasty, however internal optical urethrotomy displays rapid cure, lower scarring, and minimal hazard of infection. Purpose: To evaluate the efficacy of internal optical urethrotomy in the treatment of patients with urethral stricture. Patients \& Methods: This study was carried out at Al-Yermouk Teaching Hospital/Baghdad/Iraq in the period between January 2015 and January 2018. A group of 75 male patients (16 - 25 years of age) presented with urethral strictures had been treated with internal optical urethrotomy. Follow-up period ranged from 1 - 3 months. Outcome was graded as good, fair and poor. Results: Out of 75 patients, 28 $(37.3 \%)$ were $(21-30)$ years of age. Trauma was the most popular source of stricture found in 40 (53.3\%) and the most widespread presenting feature was poor urinary flow in $32(42.6 \%)$ patients. Stricture in the bulbous urethra in 48 (64\%) cases was found to be the most prevalent area followed by penile urethra in $16(21.3 \%)$ cases. Overall response rate was good in $52(69.3 \%)$ patients. Eleven (14.6\%) patients exhibited only minor bleeding postoperatively with no other considerable complications. Conclusion: Internal optical urethrotomy is a dependable and effective procedure in treating urethral stricture.
\end{abstract}

\section{Keywords}

Optical Urethrotomy, Urethra, Urethral Stricture, Penile

\section{Introduction}

Urethral stricture commences as fibrous lesion of urethralmucosa with decreased lumen and eventual symptomcomplex [1]. This narrowing blocks the 
urine flow producing proximal urethral dilatation [2]. The overall stricture incidence is $0.6 \%$ in particular populations [3].

Urethral strictures are a recurrent cause of adult lower urinary tract troubles, like infection of urinary tract, acute urine retention, elevated voiding pressure producing secondary thickening and irritability of the bladder, diverticula or fistulas and abscess of the perineum [4].

Blunt perineal injury, urethral instrumentation, lichen sclerosus, and sexually transmitted diseases are the utmost repeated source of strictures; great portions are iatrogenic [5].

Patients who have urethral strictures often times exhibit obstructive emptying symptoms and urinary tract infections like infection of the epididymis or prostate gland [6].

The treatment patterns differ in accordance with site, stricture extent and etiological factors [7]. At present, urethral strictures treatment comprises many options, like dilation, urethrotomy, stent and reconstructive surgical procedures [8].

Most urethral stricture patients are treated with optical internal urethrotomyutilizing a soft mobile scalpel to slit the stricture under direct view. In fact this procedure is employed as the fundamental treatment of recent in addition to recurrent strictures [9] [10] [11] [12]. Generally an average recovery of 20\% $30 \%$ is attained with optical urethrotomy [13].

The objective of our study was to appreciate the place of optical urethrotomy in treatment of urethral stricture and to shed the light on post procedure complications and their relation to sample variables. (Estimate the symptomatic perfection and effectiveness of this treatment option).

Novelty: This study was the first study conducted in our center to evaluate the use of optical urethrotomy procedure among our patients providing a baseline for future studies.

\section{Patients and Methods}

This study was carried out at Al-Yermouk Teaching Hospital/Baghdad/Iraq in the period between January 2015 and January 2018.

A group of Seventy five male patients, with an age ranged from $16-52$ years (mean age 36.3 years) presenting with history of urethral stricture, were included in the study. Exclusion criteria were patients with neurological deficit, diabetes mellitus, bladder stone, enlarged prostate \& meatal stenosis.

All patients were evaluated clinically via medical history, physical examination \& laboratory evaluation by doing urinalysis, urine culture \& sensitivity, blood urea, serum creatinine levels, blood sugar \& complete blood picture along with abdominal \& pelvic ultrasonography. The urethral stricture was diagnosed primarily by performing uroflowmetry \& retrogade urethrogram ... However, the final diagnosis was established by urethroscopy.

The procedure was performed undergeneral or spinal anesthesia. Patients were placed in dorsal lithotomy position \& were properly drapped. A $21 \mathrm{Fr}$ 
optical internal urethrotome with 0 telescope was introduced into the urethra aided by a guide wire to act as a guide for proper incision of the stricture which was done at 12 o'clock positions cutting the fibrous tissue until the urethroscope could pass with ease into the urinary bladder. Irrigation with normal saline (0.9\%) was used. An indwelling 16 Fr silicon urethral catheter was inserted \& left for 3 days to 2 weeks depending on the stricture length \& complexity. A prophylactic antibiotic was given prior to the procedure and continued post operatively for few days following the catheter elimination. All patients were instructed to visit the department at 1 month \& 3 monthly intervals for 1 year (mean 6 months) for subjective and clinical assessment (the caliber and force of urinary stream).

The criteria used to assess the success of the procedure were subjective feeling of the patient regarding his urinary stream, the uroflowmetry result and appearance of urethra on retrograde urethrogram. Outcome was graded as good (continuous strong urinary stream, maximum flow rate $>23 \mathrm{ml} / \mathrm{s}$ without proof of narrowing at the site of stricture on retrograde urethrogram), fair (diminished, intermittent urinary stream, maximum flow rate $>17 \mathrm{ml} / \mathrm{s}$ and irregular reduced diameter at the stricture level) \& poor (weak urinary stream, maximum flow rate $>12 \mathrm{ml} / \mathrm{s}$ with decisive narrowing at the stricture site)

Limitation of the study included the low sample size, the lack of comparison group and the sampling from one center in Baghdad city.

Univariate and bivariate statistical analysis was used, $\mathrm{P}$ values of equal or less than 0.05 were considered significant.

\section{Results}

This was a cross-sectional study that involved 75 male patients with urethral strictures; the biggest group 28 (37.4\%) patients were extending in age from 21 30 years. Table 1 illustrated the age distribution of the studied sample.

Regarding the etiological factors of stricture; as seen in Figure 1, nearly half $40(53.3 \%)$ patients had history of trauma, while $20(26.7 \%)$ patients and 10 (13.3\%) patients developed stricture secondary to iatrogenic injury and infection respectively. Idiopathic cause was found in only 5 (6.7\%) patients.

The most widespread complaint was poor urinary flow in $32(42.7 \%)$ patients followed by dribbling of urine in $16(21.3 \%)$ cases (Table 2 ).

Out of 75, $16(21.3 \%)$ patients had penile urethral stricture, 48 (64\%) had bulbar urethral stricture while in $11(14.7 \%)$ cases, the stricture was prostatomembranous. As seen in Figure 2.

Overall response rate was good in $52(69.3 \%)$ patients, fair in $15(20 \%)$ and poor in $8(10.7 \%)$ cases, Table 3.

Immediate post-operative complications included minor bleeding in $11(14.6 \%)$ patients, only one of them needed blood transfusion, fluid extravasations in 3 (4\%) patients, treated conservatively and did not require any surgical intervention. Six $(8 \%)$ cases had urinary tract infections, treated with appropriate antibiotics. 
Recurrent stricture was recorded in $8(10.7 \%)$ patients. Five of them $(6.7 \%)$ were managed through re optical urethrotomy while $3(4 \%)$ patients needed urethroplasty (Table 4 ).

Statistical analysis of the data to explore the association and relationship of post procedure complications to sample variables were illustrated in Table 5 and Table 6.

Patient with penile strictures were 29.2 times more likely to develop complications after an optical urethrotomy compared to patients with urethral stricture elsewhere.

Patients who reported a good response after the procedure were 0.05 times less likely to develop complication compared with those who reported not good responses following procedure.

Table 1. Age distribution of participants.

\begin{tabular}{cc}
\hline Age (years) & No. of patients (\%) \\
\hline$\leq 20$ & $18(24)$ \\
$21-30$ & $28(37.4)$ \\
$31-40$ & $19(25.3)$ \\
41 and above & $10(13.3)$ \\
Total & $75(100)$
\end{tabular}

Table 2. The presenting complaint in the patients.

\begin{tabular}{ccc}
\hline Presenting complaint & Frequency & Percent \\
\hline Poor urinary stream & 32 & 42.7 \\
Dribbling & 16 & 21.3 \\
Intermittency & 10 & 13.3 \\
Sense of incomplete emptying & 9 & 12.0 \\
Recurrent UTI & 5 & 6.7 \\
Urine retention & 3 & 4.0 \\
Total & 75 & 100.0 \\
\hline
\end{tabular}

Table 3. Outcome of optical urethrotomy.

\begin{tabular}{ccc}
\hline Outcome & Frequency & Percent \\
Good & 52 & 69.3 \\
Fair & 15 & 20.0 \\
Poor & 8 & 10.7 \\
Total & 75 & 100.0 \\
\hline
\end{tabular}


Table 4. Postoperative complications distribution of the sample.

\begin{tabular}{ccc}
\hline postoperative complications & Frequency & Percent \\
\hline Bleeding & 11 & 14.6 \\
Fluid extravasation & 3 & 4.0 \\
UTI & 6 & 8.0 \\
Recurrent stricture & 8 & 10.7 \\
Total & 28 & 37.3 \\
\hline
\end{tabular}

Table 5. The distribution of the studied sample by developing complications after optical uerthrotomy according to characteristic features of the sample.

\begin{tabular}{|c|c|c|c|c|c|}
\hline \multicolumn{2}{|c|}{ Characteristic features } & \multirow{2}{*}{$\begin{array}{c}\text { No complication } \\
29(65.9 \%)\end{array}$} & \multirow{2}{*}{$\begin{array}{c}\text { complication } \\
15(34.1 \%)\end{array}$} & \multirow{3}{*}{$\begin{array}{l}\text { Chi square } \\
\begin{array}{l}\mathrm{X}^{2}=0.478 \\
\text { d.f. }=1\end{array}\end{array}$} & \multirow{3}{*}{$\begin{array}{c}\text { P value } \\
0.489 \\
\text { N.S }\end{array}$} \\
\hline Ago & $<30$ & & & & \\
\hline Age & $\geq 30$ & $18(58.1 \%)$ & $13(41.9 \%)$ & & \\
\hline \multirow{3}{*}{ Etiology } & Traumatic & $24(60.0 \%)$ & $16(40.0 \%)$ & \multirow{3}{*}{$\begin{array}{c}\mathrm{X}^{2}=0.627 \\
\text { d.f. }=2\end{array}$} & \multirow{3}{*}{$\begin{array}{c}0.731 \\
\text { N.S }\end{array}$} \\
\hline & Iatrogenic & $14(70.0 \%)$ & $6(30.0 \%)$ & & \\
\hline & Infective or idiopathic & $9(60.0 \%)$ & $6(40.0 \%)$ & & \\
\hline \multirow{3}{*}{$\begin{array}{l}\text { Presenting } \\
\text { complaint }\end{array}$} & Poor urine stream & $21(65.6 \%)$ & $11(34.4 \%)$ & \multirow{3}{*}{$\begin{array}{c}\mathrm{X}^{2}=0889 \\
\text { d.f. }=2\end{array}$} & \multirow{3}{*}{$\begin{array}{c}0.641 \\
\text { N.S }\end{array}$} \\
\hline & $\begin{array}{l}\text { Dribbling, } \\
\text { intermittency }\end{array}$ & $17(65.4 \%)$ & $9(34.6 \%)$ & & \\
\hline & $\begin{array}{l}\text { Incomplete emptying, } \\
\text { UTI, urine retention }\end{array}$ & $9(52.9 \%)$ & $8(47.1 \%)$ & & \\
\hline \multirow{2}{*}{ Site } & Penile & $4(25.0 \%)$ & $12(75.0 \%)$ & \multirow{2}{*}{$\begin{array}{c}\mathrm{X}^{2}=12.334 \\
\text { d.f. }=1\end{array}$} & \multirow{2}{*}{$\begin{array}{c}0.000 \\
\text { Significan }\end{array}$} \\
\hline & Others & $43(72.9 \%)$ & $16(27.1 \%)$ & & \\
\hline \multirow{2}{*}{$\begin{array}{l}\text { Response } \\
\text { post op }\end{array}$} & Good & $40(76.9 \%)$ & $12(23.1 \%)$ & \multirow{2}{*}{$\begin{array}{c}\mathrm{X}^{2}=14.731 \\
\text { d.f. }=1\end{array}$} & \multirow{2}{*}{$\begin{array}{c}0.000 \\
\text { Significant }\end{array}$} \\
\hline & Not & $7(30.4 \%)$ & $16(69.6 \%)$ & & \\
\hline
\end{tabular}

Table 6. The binary logistic regression analysis of the studied sample.

\begin{tabular}{|c|c|c|c|c|c|c|}
\hline \multirow{2}{*}{$\begin{array}{l}\text { Characteristic features } \\
\text { of the sample }\end{array}$} & \multirow{2}{*}{ B } & \multirow{2}{*}{$\mathrm{df}$} & \multirow{2}{*}{ Sig. } & \multirow{2}{*}{ OR } & \multicolumn{2}{|c|}{ 95\% C.I. for OR } \\
\hline & & & & & Lower & Upper \\
\hline$<30$ & -0.849 & 1 & 0.215 & 0.428 & 0.112 & 1.639 \\
\hline \multicolumn{7}{|l|}{30 and above } \\
\hline Traumatic & 0.005 & 1 & 0.994 & 1.005 & 0.292 & 3.455 \\
\hline \multicolumn{7}{|l|}{ Others ${ }^{\circledast}$} \\
\hline Poor urine stream & -0.104 & 1 & 0.900 & 0.901 & 0.177 & 4.582 \\
\hline $\begin{array}{c}\text { Dribbling } \\
\text { intermittency }\end{array}$ & -0.729 & 1 & 0.375 & 0.482 & 0.096 & 2.412 \\
\hline \multicolumn{7}{|l|}{ UTI, retention ${ }^{\otimes}$} \\
\hline Penile & 3.375 & 1 & 0.000 & 29.223 & 4.885 & 174.818 \\
\hline \multicolumn{7}{|l|}{ Others ${ }^{\oplus}$} \\
\hline Good response & -2.885 & 1 & 0.000 & 0.056 & 0.013 & 0.237 \\
\hline \multicolumn{7}{|l|}{ Not ${ }^{\circledast}$} \\
\hline Constant & 1.329 & 1 & 0.168 & 3.776 & & \\
\hline
\end{tabular}




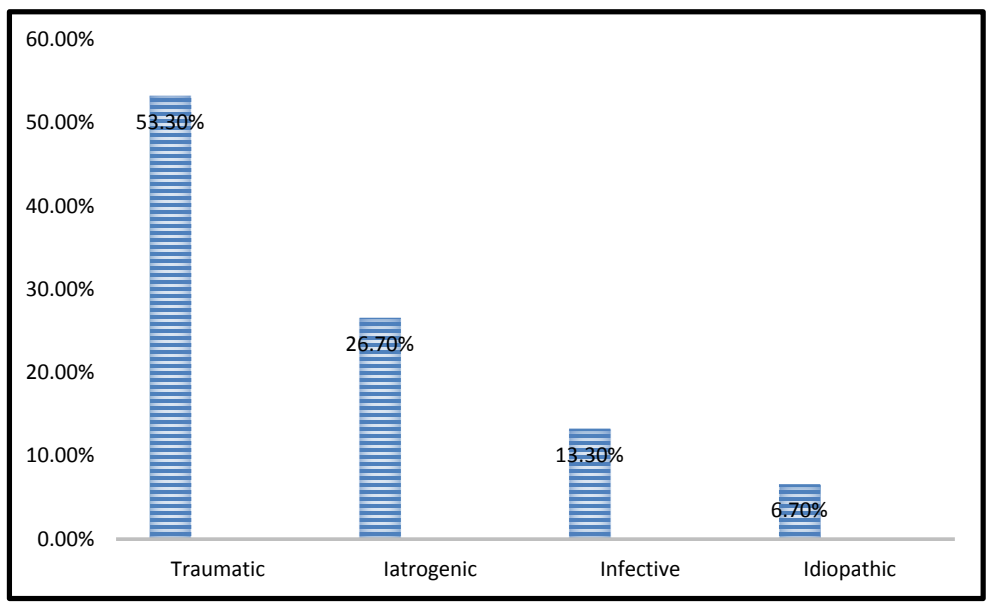

Figure 1. Etiological factors of urethral strictures.

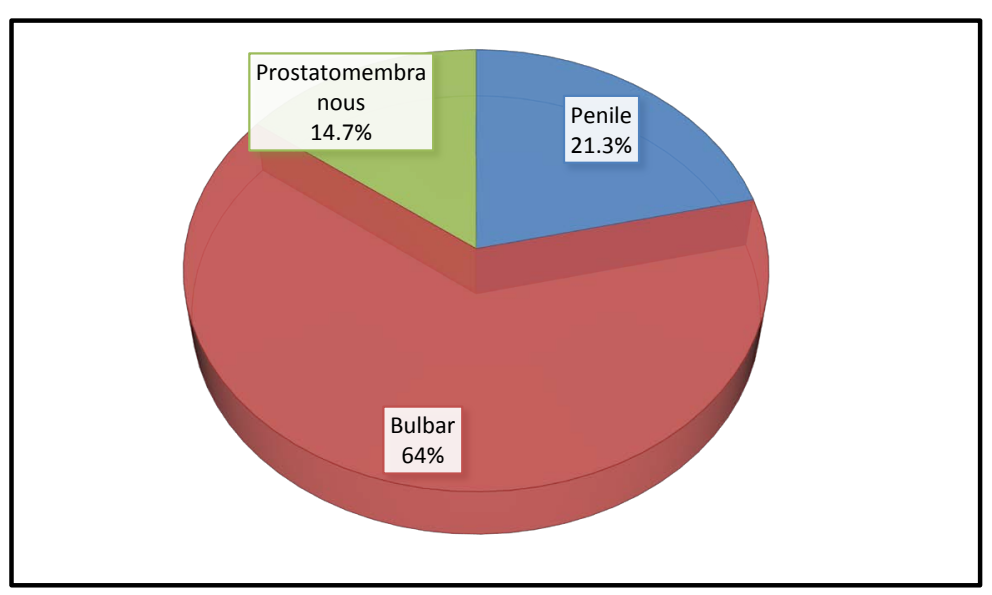

Figure 2. Site of urethral strictures.

\section{Discussion}

Nowadays internal optical urethrotomy is taken into account as the typical modality of treatment of urethral stricture because of its simplicity and easy performance which leads to worldwide popularity of this procedure for treatment of urethral stricture [14].

In our study the patients' age extended from 16 - 52 years (mean 36.3 years) which was comparable to 39 years reported by Mathur M et al. [7] but lower than the 46.9 years notified in two various studies by Balindi SS [1] and Meneghini A et al. [15], 42.2 years by Shittu OB [9].

The traumatic etiology of stricture in our study was $53.3 \%$ followed byiatrogenic injuries in $26.7 \%$ cases. These figures were consistent with $59.2 \%$ for trauma \& 27.2\% for iatrogenic injuries recorded by Mathur RK et al. [16], Shaikh NA reported trauma in 70\% patients [17]. While Younas $M$ et al. [18] stated that $70 \%$ were trauma and 30\% were iatrogenic injuries. Rasool $\mathrm{M}$ et al. declared $66.66 \%$ were traumaic [19]. On the other hand Chelton et al. [10] recorded $11.5 \%$ due to trauma. The high incidence of traumatic stricture in our study was because of road traffic mishaps \& war injuries. 
Table 7. Comparison of successrate percentage with other studies.

\begin{tabular}{ccccc}
\hline Author & Year & No. of patients & Followup (mean) & Success rate \% \\
\hline Chilton et al. [10] & 1983 & 151 & $5 \mathrm{yr}$ & 50 \\
Holm Nielsen et al. [20] & 1984 & 225 & Not specified & 77 \\
Albers et al. [21] & 1992 & 937 & $3.9 \mathrm{yr}$ & 62 \\
Pansadoro et al. [13] & 1996 & 224 & $8 \mathrm{yr}$ & 32 \\
Steenkamp et al. [22] & 1997 & 101 & $14.4 \mathrm{mo}$ & 77 \\
Santucci et al. [23] & 2010 & 74 & $14 \mathrm{mo}$ & 8 \\
Present study & 2018 & 75 & $6 \mathrm{mo}$ & 69.3 \\
\hline
\end{tabular}

As regard to urethral stricture sites, $48(64 \%)$ of the patients in the present study had stricture of bulbar urethra which was lower than that of Ali MN [14] recorded $70 \%$ to $80 \%$ of the stricture in such site \& Younas M et al. [18] reporting 73.33\% involvement of the bulbar urethra.

In our study, in $52(69.3 \%)$ patients, the response to optical urethrotomy was good while 8 (10.7\%) were having poor response. These were quite comparable with Holm-Nielsen et al. [20] reported success rate 77\% \& Pansadoro V [13] reported $11 \%$ poor results (Table 7 ).

In our series, the most common post-operative complication was bleeding noted in $14.6 \%$ which was minor bleed \& ceased in one day of hospital stay. This number was fair by matching with other studies (Younas M [18] \& Shaikh NA [17]), however it was higher than $4.4 \%$ notified by Balindi SS [1]. The fluid extravasation occurred in $4 \%$ of our patients which was identical to $2.5 \%$ recorded by Shittu OB et al. [9]. Nevertheless it dissolved within 2 days. Post-operatively, urinary tract infection happened in $8 \%$ patients. This was due to indwelling catheter and responded to treatment with appropriate antibiotic. In our series, postoperative urethral stricture was manifested in $10.7 \%$ cases.

This was consistent with $9.2 \%$ recorded by Mathur RK et al. [16] but lower than that of $26.2 \%$ by Shaikh NA et al. [17].

\section{Conclusion}

Internal optical urethrotomy is an effective, dependable, repeatable and minimally invasive method for patients with urethral stricture.

\section{Conflicts of Interest}

The authors declare no conflicts of interest regarding the publication of this paper.

\section{References}

[1] Balindi, S.S. (2007) Optical Internal Urethrotomyin the Treatment of Urethral Stricture Disease. DMJ, 1, 49-57.

[2] McAninch, J.W. (2003) Disorders of the Penis and Maleurethra. In: Tanagho, E.A. 
and McAninch, J.W., Eds., Smith's General Urology, 16th Edition, Aplleton and Lange, USA, 436-445.

[3] Tonkin, J.B. and Jordan, G.H. (2009) Management of Distal Anterior Urethral Strictures. Nature Reviews Urology, 6, 533-538.

https://doi.org/10.1038/nrurol.2009.181

[4] Waxman, S.W. and Morey, A.F. (2006) Management of Urethral Strictures. Lancet, 367, 1379-1380. https://doi.org/10.1016/S0140-6736(06)68592-9

[5] Tritschler, S., Roosen, A., Füllhase, C., et al. (2013) Urethral Stricture: Etiology, Investigation and Treatments. Deutsches Ärzteblatt International, 110, 220-226.

[6] Jordan, G.H. and Schlossberg, S.M. (2002) Surgery of the Penisand Urethra. In: Walsh, P.C., Retik, A.B., Vaughan Jr., E.D. and Wein, A.J., Eds., CampbelP s Urology, 8th Edition, WB Saunder, Philadelphia, 3886-3952.

[7] Mathur, M., Nayak, D., Aggarwal, G., Shukla, A., Khan, F. and Odiya, S. (2011) A Retrospective Analysis of Urethral Strictures and Their Management at a Tertiary Care Center. Nephro-Urology Monthly, 3, 109-113.

[8] Peterson, A.C. and Webster, G.D. (2004) Management of Urethral Stricture Disease: Developing Options for Surgical Intervention. BJU International, 94, 971-976. https://doi.org/10.1111/j.1464-410X.2004.05088.x

[9] Shittu, O.B. (2001) Internal Optical Urethrotomy in the Management of Urethral Strictures in Nigerians: Technique and Outcome. African Journal of Urology, 7, 62-65.

[10] Chilton, C.P., Shah, P.J.R., Fowler, C.G., Tiptaft, R.C. and Blandy, J.P. (1983) The Impact of Optical Urethrotomy on the Management of Urethral Strictures. British Journal of Urology, 55, 705-710. https://doi.org/10.1111/j.1464-410X.1983.tb03410.x

[11] Malik, M.A. and Sial, S.J.H. (2003) Urethral Stricture: A Prospective Study of 150 Cases at Department of Urology, Allied Hospital Faisalabad. The Professional Medical Journal, 10, 113-116.

[12] Gnanaraji, J., Devasia, A., Gnanaraji, L. and Pandey, A.P. (1999) Intermittent Self Catheterization versus Regular Outpatient Dilatation in Urethral Stricture: A Comparison. ANZ Journal of Surgery, 69, 41-43. https://doi.org/10.1046/j.1440-1622.1999.01490.x

[13] Pansadoro, V. and Emiliozzi, P. (1996) Internal Urethrotomy in the Management of Anterior Urethral Strictures: Long-Term Followup. Journal of Urology, 156, 73-75. https://doi.org/10.1016/S0022-5347(01)65942-1

[14] Ali, M.N. (2001) Experience with Cold Knife Optical Internal Urethrotomy. Journal of College of Physicians and Surgeons Pakistan, 11, 693-695.

[15] Menghini, A., Cacciola, A., Cavarretta, L., Abatangelo Ferrarese, P. and Tasca, A. (2001) Bulbar Urethral Stricture Repair with Mucosa Graft Urethroplasty. European Urology, 39, 64-67.

[16] Mathur, R.K., Adittya, K.S. and Jitendra, G. (2009) Comprehensive Analysis and Urethroscopic Evaluation of "U" shaped prostatobulbar Anastomotic Urethroplasty. Asian Journal of Surgery, 32, 151-156. https://doi.org/10.1016/S1015-9584(09)60386-9

[17] Shaikh, N.A., Shaikh, M.N. and Anwar, S. (2005) Comparison of Optical Urethrotomy with Perineal Urethroplasty in the Management of Traumatic Blind Posterior Urethral Stricture. Pakistan Journal of Medical Research, 44, 117-121.

[18] Younas, M., Amanullah, A., Rehman, A.U., Khan, W.Y., Khan, I. and Ali, M.N. 
(2006) Outcome of Internal Optical Urethrotomy in Urethral Strictures: A Prospective Study. JPMI, 20, 48-51.

[19] Rasool, M., Tabasum, S.A., Nazeem, C.F. and Ali, M.T. (2001) Treatment Modalities of Urethral Stricture. Journal of the College of Physicians and Surgeons-Pakistan, 11, 715-718

[20] Holm-Nielsen, A., Schultz, A. and Moller-Pedersen, V. (1984) Direct Vision Internal Urethrotomy: A Critical Review of 365 Operations. British Journal of Urology, 56, 308-312. https://doi.org/10.1111/j.1464-410X.1984.tb05393.x

[21] Albers, P., Fichtner, J., Bruhl, P. and Muller, S.C. (1996) Long-Term Results of Internal Urethrotomy. Journal of Urology, 156, 1611-1614. https://doi.org/10.1016/S0022-5347(01)65461-2

[22] Steenkamp, J.W., Heyns, C.F. and DeKock, M.I. (1997) Internal Urethrotomy versus Dilatation as Treatment for Male Urethral Strictures. A Prospective Randomized Comparison. Journal of Urology, 157, 98-101. https://doi.org/10.1016/S0022-5347(01)65296-0

[23] Santucci, R.A. and Eisenberg, L. (2010) Urethrotomy Has a Much Lower Success Rate than Previously Reported. Journal of Urology, 183, 1859-1862.

https://doi.org/10.1016/j.juro.2010.01.020 